\title{
Peran Serta Orang Tua dan Dampak Hospitalisasi pada Anak Usia 3-6 Tahun di Ruang Anak RSUD Poso
}

\author{
Nurfatimah \\ Prodi D-III Kebidanan Poso Jurusan Kebidanan Poltekkes Kemenkes Palu \\ Email Korespondensi: nfatimahhh@gmail.com
}

\begin{abstract}
Article Info
ABSTRACT

Article history:

Submitted: 2019-06-26

Accepted: 2019-08-28

Published: 2019-08-31

Keywords:

Hospitality;

the role of Parents;

Hospitalization is a process for reasons of planning or emergency that requires children to stay in the hospital to undergo therapy and treatment. The general objective of this tusy was to know the description of the participation of parents and the impact of hospitalization on children aged 3-6 years. This research used descriptive research method. The population in this study were all parents who have children aged 3-6 years who were treated in the Children's Room of Poso Regional Hospital as many as 48 children. The sampling technique was total sampling and the sample in this study were all parents who have children aged 3-6 years who are treated. The statistical test used was the Chi-Square test. The results showed that $64.7 \%$ of respondents had a good role and $58.8 \%$ of respondents had children who were less affected by hospitalization. $77.3 \%$ of respondents who had good parents have children who were less affected by hospitalization. The conclusion of this study was the role of good parents can reduce the impact of hospitalization on children. This research suggests to reduce the impact of hospitalization on children, hospitals should create play programs for children so that children who are treated in hospitals do not feel bored while getting treatment.
\end{abstract}

\section{ABSTRAK}

Kata Kunci:

Hospitalisasi; Peran Orang tua;
Hospitalisasi merupakan suatu proses karena alasan berencana atau darurat yang mengharuskan anak untuk tinggal di rumah sakit untuk menjalani terapi dan perawatan. Tujuan umum untuk mengetahui gambaran peran serta orang tua dan dampak hospitalisasi pada anak usia 3-6 tahun. Penelitian ini menggunakan metode penelitian deskriptif. Populasi dalam penelitian ini adalah semua orang tua yang mempunyai anak usia 3-6 tahun yang dirawat di Ruang Anak RSUD Poso yang berjumlah 48 anak. Teknik pengambilan sampel adalah Total Sampling dan sampel pada penelitian ini adalah semua orang tua yang mempunyai anak usia 3-6 tahun yang sedang dirawat. Uji statistik yang digunakan adalah uji chy square. Hasil penelitian menunjukan $64,7 \%$ responden memiliki peran yang baik dan $58,8 \%$ responden memiliki anak yang kurang mengalami dampak hospitalisasi. $77,3 \%$ responden yang peran serta orang tua yang baik memiliki anak yang kurang mengalami dampak hospitalisasi. Kesimpulan penelitian ini adalah peran serta orang tua yang baik bisa mengurangi dampak hospitalisasi pada anak. 


\section{PENDAHULUAN}

Anak usia 3-6 tahun adalah anak yang mempunyai berbagai macam potensi. Potensi-potensi itu di rangsang dan di kembangkan agar pribadi anak tesebut berkembang secara optimal. Hospitalisasi merupakan suatu proses karena alasan berencana atau darurat yang mengharuskan anak untuk tinggal di rumah sakit untuk menjalani terapi dan perawatan. ${ }^{1}$

Usia 3-6 tahun sangat rentan terhadap efek stres dan ketakutan selama rawat inap. Anak-anak di bawah usia enam tahun mampu berpikir tentang suatu peristiwa secara keseluruhan, belum bisa menentukan perilaku yang dapat mengatasi suatu masalah yang baru dihadapi dan kurang memahami suatu peristiwa yang dialami. ${ }^{2}$ Anak-anak mengatasi ketakutan berdasarkan pengalaman yang pernah dialami dan strategi koping yang pernah dilakukan. Anak usia 3-6 tahun belum dapat mengekspresikan emosi dan harapan mereka dengan cukup baik secara lisan.

Dampak dari hospitalisasi khususnya bagi pasien anak-anak diantaranya kecemasan, merasa asing akan lingkungan yang baru, berhadapan dengan sejumlah individu yang belum dikenal, perubahan gaya hidup dari yang biasa, serta harus menerima tindakan medik atau perawatan yang menyakitkan. Anak-anak yang dirawat lebih dari 2 (dua) minggu memiliki resiko mengalami gangguan bahasa dan perkembangan keterampilan kognitif, serta pengalaman buruk di rumah sakit sehingga dapat merusak hubungan dekat antara ibu dan anak. Anak yang belum pernah dirawat lebih sulit beradaptasi dengan situasi di rumah sakit dibandingkan dengan anak yang telah mengalaminya. ${ }^{3}$

Pentingnya peran keluarga dalam hal ini orang tua untuk mendampingi anak usia 3-6 tahun saat hospitalisasi diharapkan bisa memberikan rasa aman, nyaman dan kasih sayang serta motivasi yang kuat kepada anak sehingga anak akan merasa lebih siap menerima semua tindakan medis maupun tindakan keperawatan lainya, kesiapan anak dalam menerima tindakan medis ini akan sangat membantu dalam proses penyembuhan. ${ }^{1}$

Penelitian yang dilakukan oleh Winarsih (2012) tentang hubungan peran serta orang tua dengan dampak hospitalisasi pada anak usia prasekolah di RSUD RA Kartini Jepara menunjukkan bahwa ada hubungan yang signifikan antara peran serta orang tua dan dampak hospitalisasi pada anak prasekolah. Keterlibatan orang tua dalam perawatan membuat anak mampu mengembangkan diri secara pribadi dan memberikan sikap positif orang tua sehingga perawatan pada anak lebih optimal. ${ }^{4}$

Dari data yang didapat di bagian Rekam Medik RSUD Poso, jumlah anak yang di rawat di Ruang Anak selama 3 tahun terakhir menurun, pada tahun 2014 sebanyak 1.566 anak, pada tahun 2015 sebanyak 1.405 anak, dan pada tahun 2016 sebanyak 1.396 anak. Tetapi, dari data tersebut jumlah anak usia 3-6 tahun yang dirawat meningkat, pada tahun 2015 sebanyak 366 anak, tahun 2016 sebanyak 450 anak, dan pada Januari-Februari 2017 sebanyak 48 anak. ${ }^{5}$ Diperoleh keterangan bahwa anak yang menjalani perawatan biasanya menunjukkan dampak hospitalisasi seperti menangis ketika akan dilakukan tindakan medis atau tindakan keperawatan, bersandar pada orang tuanya, anak tidak mau menjawab pertanyaan perawat atau orang baru yang ditemuinya, anak terlihat takut pada perawat yang datang karena trauma dengan tindakan invasive yang dilakukan pada hari sebelumnya.

Berdasarkan survei awal penelitian ini didapatkan setiap kali perawat melakukan tindakan seperti pemasangan infus dan injeksi orang tua pasien menolak untuk mendampingi anaknya dengan alasan tidak tega melihat perlakuan menyakitkan terhadap anaknya, sehingga anak seringkali menangis, memberontak dan bahkan menendang perawat. Hal ini terjadi karena masih ada beberapa orang tua yang tidak 
memperhatikan pentingnya peran keluarga, ditandai dengan orang tua yang tidak mampu meminimalisir dampak perpisahan seperti tidak menemani anak ketika dilakukan tindakan medis, tidak menghadirkan teman sebaya dan mainan kesayangan. Tujuan dari penelitian ini adalah untuk mengetahui gambaran peran serta orang tua dan dampak hospitalisasi pada anak usia 3-6 tahun.

\section{METODE PENELITIAN}

Desain penelitian yang digunakan adalah cross sectional. Penelitian ini dilakakukan di Ruang Anak RSUD Poso. Populasi dalam penelitian ini adalah semua orang tua yang mempunyai anak usia 3-6 tahun yang di rawat di Ruang Anak RSUD Poso yang berjumlah 48 anak. Sampel pada penelitian ini adalah semua orang tua yang mempunyai anak usia 3-6 tahun yang dirawat di Ruang Anak RSUD Poso. Variabel yang diteliti adalah peran orang tua dan dampak hospitalisasi pada anak. Teknik pengumpulan data dalam penelitian ini adalah pengisian kuesioner. Uji yang digunakan adalah uji chi square.

\section{HASIL PENELITIAN}

Setelah data penelitian dianalisis maka diperoleh hasil sebagai berikut:

Tabel 1. Distribusi Frekuensi Berdasarkan Karakteristik Anak, Karakteristik Orang Tua, Peran Serta Orang Tua dan Dampak Hospitalisasi Anak di Ruang Anak RSUD Poso

\begin{tabular}{|c|c|c|}
\hline Variabel & Frekuensi & Persentase \\
\hline \multicolumn{3}{|l|}{ Karakteristik Anak } \\
\hline \multicolumn{3}{|l|}{ Jenis Kelamin } \\
\hline Laki-laki & 17 & 50,0 \\
\hline Perempuan & 17 & 50,0 \\
\hline \multicolumn{3}{|l|}{ Umur Anak } \\
\hline 3 tahun & 10 & 29,4 \\
\hline 4 tahun & 5 & 14,7 \\
\hline 5 tahun & 12 & 35,3 \\
\hline 6 tahun & 7 & 20,6 \\
\hline \multicolumn{3}{|l|}{ Lama Rawat } \\
\hline 1 hari & 6 & 17,6 \\
\hline 2 hari & 15 & 44,1 \\
\hline 3 hari & 1 & 2,9 \\
\hline 4 hari & 8 & 23,5 \\
\hline 6 hari & 3 & 8,8 \\
\hline 21 hari & 1 & 2,9 \\
\hline \multicolumn{3}{|c|}{ Riwayat dirawat sebelumnya } \\
\hline Belum pernah & 15 & 44,1 \\
\hline Pernah & 19 & 55,9 \\
\hline \multicolumn{3}{|c|}{ Karakteristik Orang tua } \\
\hline \multicolumn{3}{|l|}{ Orang tua } \\
\hline Ayah & 5 & 14,7 \\
\hline Ibu & 29 & 85,3 \\
\hline \multicolumn{3}{|l|}{ Umur orang tua } \\
\hline 20-35 tahun & 22 & 64,7 \\
\hline$>35$ tahun & 12 & 35,3 \\
\hline \multicolumn{3}{|l|}{ Pendidikan orang tua } \\
\hline SLTP & 7 & 20,6 \\
\hline SMA & 22 & 64,7 \\
\hline PT/ Diploma & 5 & 14,7 \\
\hline
\end{tabular}




\begin{tabular}{lcc}
\hline \multicolumn{1}{c}{ Variabel } & Frekuensi & Persentase \\
\hline Pekerjaan Orang tua & & \\
$\quad$ Tidak bekerja & 19 & 55,9 \\
$\quad$ Bekerja & 15 & 44,1 \\
$\begin{array}{l}\text { Pengalaman merawat anak } \\
\quad \text { Tidak pernah }\end{array}$ & 9 & 26,5 \\
$\quad$ Pernah & 25 & 73,5 \\
Peran serta orang tua & 22 & 64,7 \\
$\quad$ Baik & 12 & 35,3 \\
$\quad$ Kurang Baik & & \\
Dampak Hospitalisasi & & \\
$\quad$ Kurang Berdampak & 20 & 58,8 \\
$\quad$ Berdampak & 14 & 41,2 \\
\hline
\end{tabular}

Sumber: Data primer, 2018

Berdasarkan tabel 1 menunjukkan bahwa karakteristik anak berdasarkan jenis kelamin anak sama (50\%) laki-laki dan (50\%) perempuan, usia anak terbanyak adalah 5 tahun (35,3\%), lama dirawat anak yang paling banyak adalah 2 hari yaitu 15 anak $(44,1 \%)$, riwayat anak yang pernah dirawat sebelumnya yang terbanyak adalah pernah dirawat sebanyak 19 orang (55,9\%). Karakteristik orang tua berdasarkan orang tua yang terbanyak adalah ibu yaitu 29 responden $(85,3 \%)$, usia orang tua terbanyak adalah usia 20-35 tahun yaitu 22 responden (64,7\%), pendidikan orang tua terbanyak adalah SMA yaitu 22 responden $(64,7 \%)$, pekerjaan orang tua terbanyak adalah Tidak bekerja yaitu 19 responden (55,9\%), pengalaman merawat anak di Rumah sakit yang terbanyak adalah pernah yaitu 25 responden (73,5\%). Peran serta orang tua yang baik sebanyak 22 responden (64,7\%), serta dampak hospitalisasi pada anak di rumah sakit adalah kurang berdampak berdampak yaitu sebanyak 20 orang $(58,8 \%)$.

Tabel 2. Distribusi Peran Serta Orang Tua berdasarkan Dampak Hospitalisasi Anak di Ruang Anak RSUD Poso

\begin{tabular}{|c|c|c|c|c|c|c|c|}
\hline \multirow{3}{*}{$\begin{array}{c}\text { Peran Serta } \\
\text { Orang Tua }\end{array}$} & \multicolumn{4}{|c|}{ Dampak Hospitalisasi } & \multirow{2}{*}{\multicolumn{2}{|c|}{ Jumlah }} & \multirow{3}{*}{ Nilai $p$} \\
\hline & \multicolumn{2}{|c|}{$\begin{array}{c}\text { Kurang } \\
\text { Berdampak }\end{array}$} & \multicolumn{2}{|c|}{ Berdampak } & & & \\
\hline & $f$ & $\%$ & $\mathbf{F}$ & $\%$ & $\mathbf{f}$ & $\%$ & \\
\hline Baik & 17 & 77,3 & 5 & 22,7 & 22 & 100 & \\
\hline Kurang Baik & 3 & 25 & 9 & 75 & 12 & 100 & 0,005 \\
\hline Jumlah & 20 & 58,8 & 14 & 41,2 & 34 & 100 & \\
\hline
\end{tabular}

Berdasarkan tabel 2 menunjukkan bahwa peran serta orang tua yang baik dan anak yang kurang mengalami dampak hospitalisasi adalah 17 responden $(77,3 \%)$. Peran serta orang tua yang kurang baik dan anak yang mengalami dampak hospitalisasi adalah 9 responden (75\%).

\section{PEMBAHASAN}

Berdasarkan hasil penelitian pada tabel 2 menunjukkan bahwa peran serta orang tua yang baik dan anak yang kurang mengalami dampak hospitalisasi adalah 17 responden (77,3\%). Peran serta orang tua yang kurang baik dan anak yang mengalami dampak hospitalisasi adalah 9 responden (75\%).

Hal ini menunjukkan bahwa semakin baik peran serta orang tua bisa mengurangi dampak hospitalisasi pada anak. Karena dalam perawatan anak di rumah sakit orang tua mampu menjalankan perannya dalam pemenuhan kebutuhan personal 
hygiene, pemenuhan kebutuhan nutrisi, membantu tindakkan keperawatan, pemenuhan kebutuhan psikologis, memberi dukungan saat anak menerima tindakan medis, pemenuhan kebutuhan spiritual. Orang tua mampu sebagai pelindung bagi anak. Hal ini sesuai dengan pendapat Harmoko bahwa peran orang tua baik karena ada dukungan untuk memberi perawatan pada anak dalam hal merawat, mendidik, mendorong dan mengawas dari orang tua yang secara keseluruhan membuat anak lebih baik, dimana ketika anak dirawat di rumah sakit peran orang tua menjadi bertambah. ${ }^{6}$

Peran orang tua baik karena adanya dukungan untuk memberi perawatan pada anak yang sakit, seperti membantu melayani anak untuk makan dan juga memberikan dukungan pada anak selama mendapat terapi intravena. Hal ini sangat di butuhkan anak karena selama perawatan di rumah sakit anak akan sering mendapat terapi intravena sesuai dengan diagnosis penyakitnya. Selain itu, peran serta orang tua dalam pemenuhan kebutuhan psikologis anak akan sangat membantu dalam proses penyembuhan dan akan mengurangi dampak hospitalisasi pada anak seperti memberikan kenyamanan pada anak dengan memeluk, mencium, dan berbicara pada anak. Sehingga anak akan lebih nyaman berada di rumah sakit. Kegiatan yang telah diupayakan keluarga pasien tersebut sesuai dengan pendapat Potter dan Perry yang menyatakan bahwa keluarga atau orang tua berperan sebagai salah satu sumber kekuatan dalam upaya penanganan masalah keperawatan. ${ }^{7}$

Peran informal orang tua yang dominan terhadap dampak hospitalisasi anak usia 3-6 tahun adalah peran sebagai sahabat, dengan keakraban dan kedekatan pada orang tua dapat mengurangi kesedihan seorang anak. Hal ini dapat dilakukan dengan cara mengorganisasi dan merencanakan kegiatan dalam upaya mempertahankan kesehatan anak. $^{8}$

Terdapat hubungan yang signifikan antara peran serta orang tua dan dampak hospitalisasi pada anak prasekolah. Keterlibatan orang tua dalam perawatan membuat anak mampu mengembangkan diri secara pribadi dan memberikan sikap positif orang tua sehingga perawatan pada anak lebih optimal. ${ }^{9}$

Hasil observasi yang dilakukan peneliti terlihat bahwa peran serta orang tua yang baik dilihat dari cara berkomunikasi dengan anak yang membantu mengatasi perasaan cemas pada saat akan dilakukan tindakan keperawatan, memberikan pujian saat anak kooperatif terhadap perawat. Orang tua mempersiapkan psikologis anak untuk tindakan prosedur yang akan dilakukan dan memberikan dukungan psikologis anak ${ }^{10}$. Selain itu, orang tua juga memberikan motivasi dan mengatakan serta menjelaskan bahwa tindakan yang akan diterima anak untuk membantu kesembuhan anak.

Faktor-faktor yang dapat mempengaruhi dampak hospitalisasi pada anak usia 3-6 tahun adalah kurang peran serta orang tua dalam perawatan anak, kurang nya fasilitas bermain untuk anak sehingga anak sering bosan di dalam ruangan karena selalu diam di atas tempat tidur, serta kurangnya peran perawat dalam berkomunikasi dengan anak. Cara untuk meminimalkan dampak negatif dari hospitalisasi adalah perawat melibatkan orang tua dalam perawatan dan mendorong peran serta orang tua dalam perawatan. Hal ini sejalan dengan penelitian yang dilakukan oleh Dewi yang menyatakan bahwa peran serta orang tua baik membuat dampak hospitalisasi positif pada anak karena perawat melibatkan orang tua maupun anak dalam pengambilan keputusan selama perawatan. Anak mampu mengembangkan diri sebagai pribadi dan memberikan orang tua perasaan bahwa mereka adalah bagian dari tim untuk memberikan anak perawatan secara optimal selama rawat inap. ${ }^{11}$ 
Dalam penelitian ini sebagian besar anak kurang mengalami dampak hospitalisasi selama menjalani perawatan di rumah sakit karena sebagian besar orang tua sudah mempnyai pengalaman merawat anak di rumah sakit. Berdasarkan data karakteristik responden pada penelitian ini, pengalaman orang tua merawat anak di Rumah sakit sebagian besar pernah yaitu 25 responden (73,5\%). Orang tua yang pernah merawat anaknya di RS cenderung lebih terbiasa dengan keadaan anak selama menjalani perawatan dan lebih bisa menjalankan perannya. Orangtua mengalami kecemasan yang tinggi saat perawatan anaknya di rumah sakit, walaupun beberapa orangtua juga dilaporkan tidak mengalaminya karena perawatan anak dirasakan dapat mengatasi permasalahan. Terutama pada mereka yang baru pertama kali mengalami perawatan anak di rumah sakit, dan orangtua yang kurang mendapat dukungan emosi dan sosial keluarga, kerabat bahkan petugas kesehatan akan menunjukkan perasaan cemasnya. ${ }^{1}$

Selain itu, berdasarkan data karakteristik responden pada penelitian ini, orangtua yang menunggu paling banyak adalah ibu sebanyak 29 responden $(85,3 \%)$. Sehingga dalam penelitian ini sebagian besar anak tidak mengalami dampak hospitalisasi. Ada perbedaan peran antara seorang ibu dengan seorang ayah. Seorang ibu kebanyakan lebih akrab dengan anaknya karena lebih banyak waktu yang diluangkan bersama anaknya, berbeda dengan seorang ayah yang cenderung lebih sibuk bekerja dan jarang meluangkan sehingga sosok ayah kurang berpengaruh terhadap kehidupan anak. ${ }^{1}$ Hubungan anak dengan ibu sangat dekat. Akibatnya, perpisahan dengan ibu akan menimbulkan rasa kehilangan pada anak akan orang yang terdekat bagi dirinya dan akan lingkungan yang dikenal olehnya, sehingga pada akhirnya akan menimbulkan perasaan tidak aman dan rasa cemas. Ibu memiliki sikap positif terhadap anak yang sedang dirawat. Ibu bisa memenuhi kebutuhan anak secara fisik maupun psikologis sehingga membuat anak bersikap positif terhadap kegiatan keperawatan yang sedang dijalani anak. Dalam penelitian ini, rata-rata dampak hospitalisasi yang di tunjukan anak adalah anak sering meminta pulang dan tidak mau makan. Keadaan ini terjadi karena anak mengalami perubahan dari keadaan sehat dan rutinitas lingkungan serta mekanisme koping yang terbatas dalam menghadapi stressor. Stressor utama dalam hospitalisasi adalah perpisahan, kehilangan kendali dan nyeri.

\section{SIMPULAN DAN SARAN}

Simpulan dari penelitian ini adalah $64,7 \%$ reponden memiliki peran yang baik selama perawatan anak di RS. 58,8\% responden yang memiliki anak yang kurang mengalami dampak hospitalisasi. peran serta orang tua yang baik bisa mengurangi dampak hospitalisasi pada anak. Penelitian ini menyarankan untuk mengurangi dampak hospitalisasi pada anak sebaiknya rumah sakit membuat program bermain untuk anak sehingga anak-anak yang dirawat di rumah sakit tidak merasa bosan selama mendapatkan perawatan.

\section{DAFTAR PUSTAKA}

1. Supartini Y. Buku Ajar Konsep Dasar Keperawatan Anak. Jakarta: EGC; 2004.

2. Jewett J, Peterson K. Stress and Young Children. Champaign, IL : ERIC Clearinghouse on Elementary and Early Childhood Education; 2002.

3. Commodari E. Children Staying in Hospital: a Research on Psychological Stress of Caregivers. Ital J Pediatr [Internet]. 2010 [cited 2019 Aug 1];36(1):40. Available from: http://ijponline.biomedcentral.com/articles/10.1186/1824-7288-36-40

4. Winarsih BD. Hubungan Peran Serta Orang Tua dengan Dampak Hospitalisasi pada Anak Usia Prasekolah di RSUD RA Kartini Jepara [Internet]. [Depok]: Fakultas IImu 
Keperawatan, Universitas Indonesia; 2012. Available from: http://lib.ui.ac.id/file?file=digital/20304340-T30718\%20-\%20Hubungan\%20peran.pdf

5. RSUD Poso. Data Pelayanan Kesehatan Anak. Poso: RSUD Poso; 2017.

6. Harmoko. Asuhan Keperawatan Keluarga. Yogyakarta: Pustaka Pelajar; 2012.

7. Potter PA, Perry AG, Hall A, Stockert PA, editors. Fundamentals of Nursing. Ninth edition. St. Louis, Miissouri: Elsevier; 2017. 1365 p.

8. Mubarak WI, Chayatin N, Santoso BA. IImu Keperawatan Komunitas: Konsep dan Aplikasi (Buku 2). Jakarta: Salemba Medika; 2009.

9. Winarsih BD, Hartini S, Sulistyawati E. Analisis Hubungan Tingkat Kecemasan dengan Peran Orang Tua dalam Merawat Anak Hospitalisasi. Motorik [Internet]. 2018;13(26):10. Available from: ejournal.stikesmukla.ac.id/index.php/motor/article/download/339/324

10. Hockenberry M, Wilson D. Wong's Nursing Care of Infants and Children [Internet]. 11th ed. St. Louis, Missouri: Elsevier; 2018. Available from: https://www.elsevier.com/books/wongs-nursing-care-of-infants-andchildren/hockenberry/978-0-323-48538-8

11. Dewi OC. Hubungan Perilaku Caring Perawat dengan Tingkat Kecemasan Anak Usia Sekolah. [Jember]: Universitas Jember; 2014. 